\title{
Histological Changes of the Pancreas in an Elderly Diabetic Patient Positive for GAD Antibody
}

\author{
Satoshi Murao, Kyoji Hirata, Toshihiko Ishida* and Jiro Takahara*
}

\begin{abstract}
We examined the histological changes of the pancreas in a 75-year-old diabetic woman who was treated with sulphonylurea for 10 years and required insulin treatment for the subsequant 10 years. She was positive for antiglutamic acid decarboxylase antibody (GAD Ab) 20 years after the diagnosis of diabetes. Her autopsied pancreas revealed disfigured islets and no $\beta$ cells. These changes were indistinguishable from those of the long-sustained type 1 diabetes mellitus, and insulitis was not found. This case suggests that diabetic patients positive for the GAD Ab, even if oral hypoglycemic agents are effective, may develop complete $\beta$ cell destruction over a long period.

(Internal Medicine 39: 1079-1082, 2000)
\end{abstract}

Key words: type 1 diabetes mellitus, slowly progressive IDDM, insulitis

\section{Introduction}

Type 1 diabetes mellitus results from pancreatic $\beta$ cell destruction, which leads to absolute insulin deficiency. Although some type 1 diabetic patients show no evidence of autoimmunity, those positive for anti-glutamic acid decarboxylase antibody (GAD Ab) are considered to have autoimmune-mediated pancreatic $\beta$ cell destruction (1). GAD Ab is sometimes found to be positive in clinically non-insulin-requiring diabetic patients (2). The clinical course of these patients is not uniform. Insulin secretion rapidly decreases in some patients, but in others, pancreatic $\beta$ cell function remains preserved for over a decade. The natural course of GAD Ab-positive non-insulin requiring patients has not been completely clarified. Histological study of the pancreas in these patients would provide some information regarding its pathophysiology. We report a GAD Ab-positive diabetic woman who was treated with sulphonylurea for 10 years and required insulin treatment for the subsequant 10 years; the histological findings of her pancreas obtained by autopsy are presented.

\section{Case Report}

A 75-year-old woman was referred to our hospital in 1996, for the treatment of diabetes mellitus and nephrotic syndrome. She was diagnosed with diabetes mellitus at the age of 55 and treated with sulphonylurea for 10 years. At 65 years of age, she required insulin treatment. None of her parents, six siblings or three offspring, had been diagnosed with diabetes mellitus. She was admitted to our hospital in August 1996.

On admission, her height was $150 \mathrm{~cm}$, and body weight was $43 \mathrm{~kg}$. She had proliferative diabetic retinopathy, although panretinal photocoagulation had been performed. Her white blood cell count was $7,800 / \mu 1$ with a normal fraction, red blood cell count was $242 \times 10^{4} / \mu \mathrm{l}$, hemoglobin was $7.0 \mathrm{~g} / \mathrm{dl}$, hematocrit was $21 \%$ and platelet count was $9.2 \times 10^{4} / \mu 1$. The result of liver function tests was normal. Serum total protein was $4.9 \mathrm{~g} /$ $\mathrm{dl}$ and the gamma globulin fraction was increased to $24.6 \%$, blood urea nitrogen was $21 \mathrm{mg} / \mathrm{dl}$, and creatinine was $1.1 \mathrm{mg} /$ dl. Excretion of urinary protein was $7.9 \mathrm{~g} /$ day, and creatinine clearance was $17 \mathrm{ml} / \mathrm{min}$. These results indicated that her anemia was caused by renal failure and recombinant erythropoietin was administered. On thyroid function tests, her thyroid stimulating hormone level was $20.3 \mu \mathrm{U} / \mathrm{ml}$, free T3 was 2.1 $\mathrm{pg} / \mathrm{ml}$, free T4 was $0.7 \mathrm{ng} / \mathrm{dl}$, and tests for both antimicrosome antibody and thyroglobulin antibody were positive. The presence of chronic thyroiditis was suspected, and she was prescribed levothyroxine sodium for the treatment of hypothyroidism. The serum level of C-peptide immunoreactivity was below $0.1 \mathrm{ng} / \mathrm{ml}$ both before and 6 minutes after $1 \mathrm{mg}$ glucagon loading test. A test for GAD Ab revealed $19.1 \mathrm{U} / \mathrm{ml}$ (recombinant human GAD65 is used as an antigen, normal range $<1.5 \mathrm{U} / \mathrm{ml}$ ). Neither islet cell antibody (ICA) nor IA-2 antibody (IA-2 Ab) was detected, and insulin antibody assessed by non-specific binding was $6.5 \%$, which was within the normal range.

Renal failure progressed, and she died in August 1997. An

From the Department of Internal Medicine, Matsuyama Shimin Hospital, Ehime and *the First Department of Internal Medicine, Kagawa Medical University, Kagawa

Received for publication February 15, 2000; Accepted for publication July 12, 2000

Reprint requests should be addressed to Dr. Satoshi Murao, the Department of Internal Medicine, Matsuyama Shimin Hospital, 2-6-5, Oo-te machi, Matsuyama, Ehime 790-0067 
autopsy was performed. Her pancreas was markedly atrophied and weighed $32 \mathrm{~g}$. Specimens were fixed in formalin and embedded in paraffin. Sections were stained with hematoxylin and eosin and immunohistochemically using the avidin-biotin- peroxidase complex method for chromogranin A, chromogranin $\mathrm{B}$, insulin, glucagon, and somatostatin. In order to detect the infiltrating inflammatory cells, we also used LCA, L26, UCHL1, and Leu 1 antibody. The islets were of various sizes with

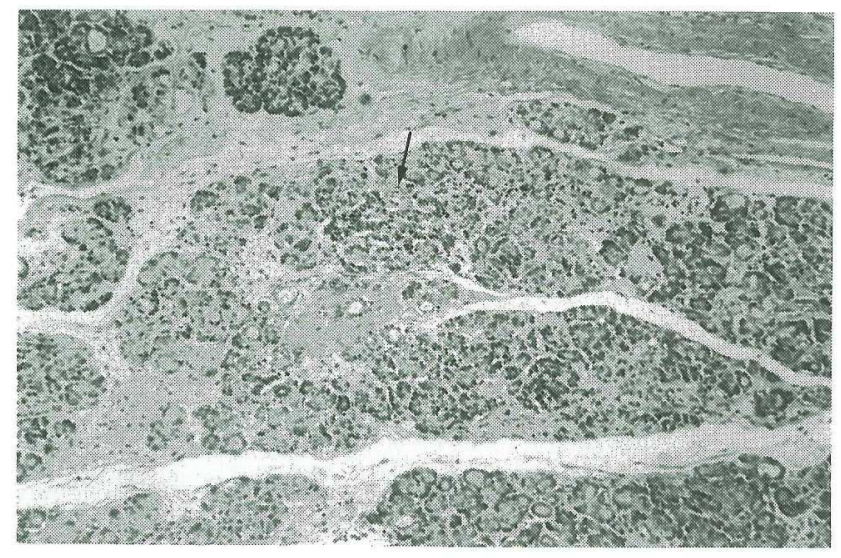

Figure 1. HE staining shows disfigured islets (arrow) $(\times 25)$.

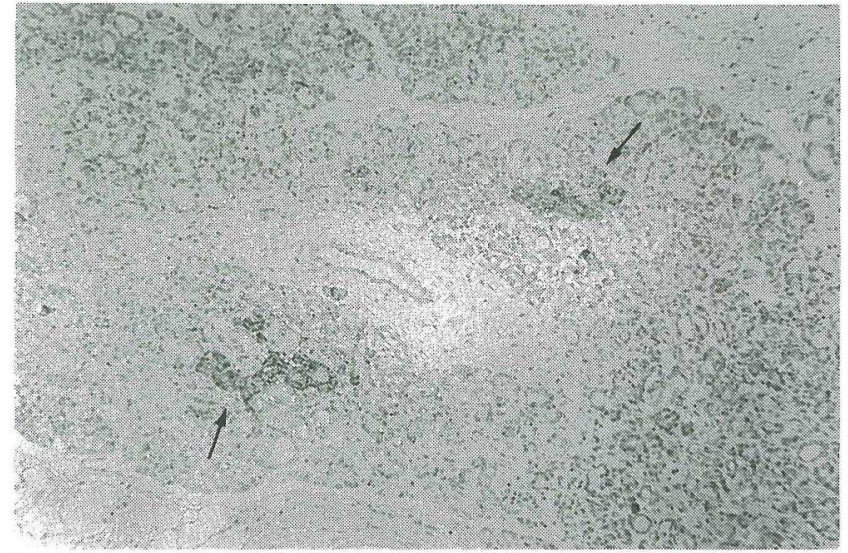

Figure 2. Immunohistological staining of chromogranin A, B. Islets are disfigured (arrows) $(\times 25)$.
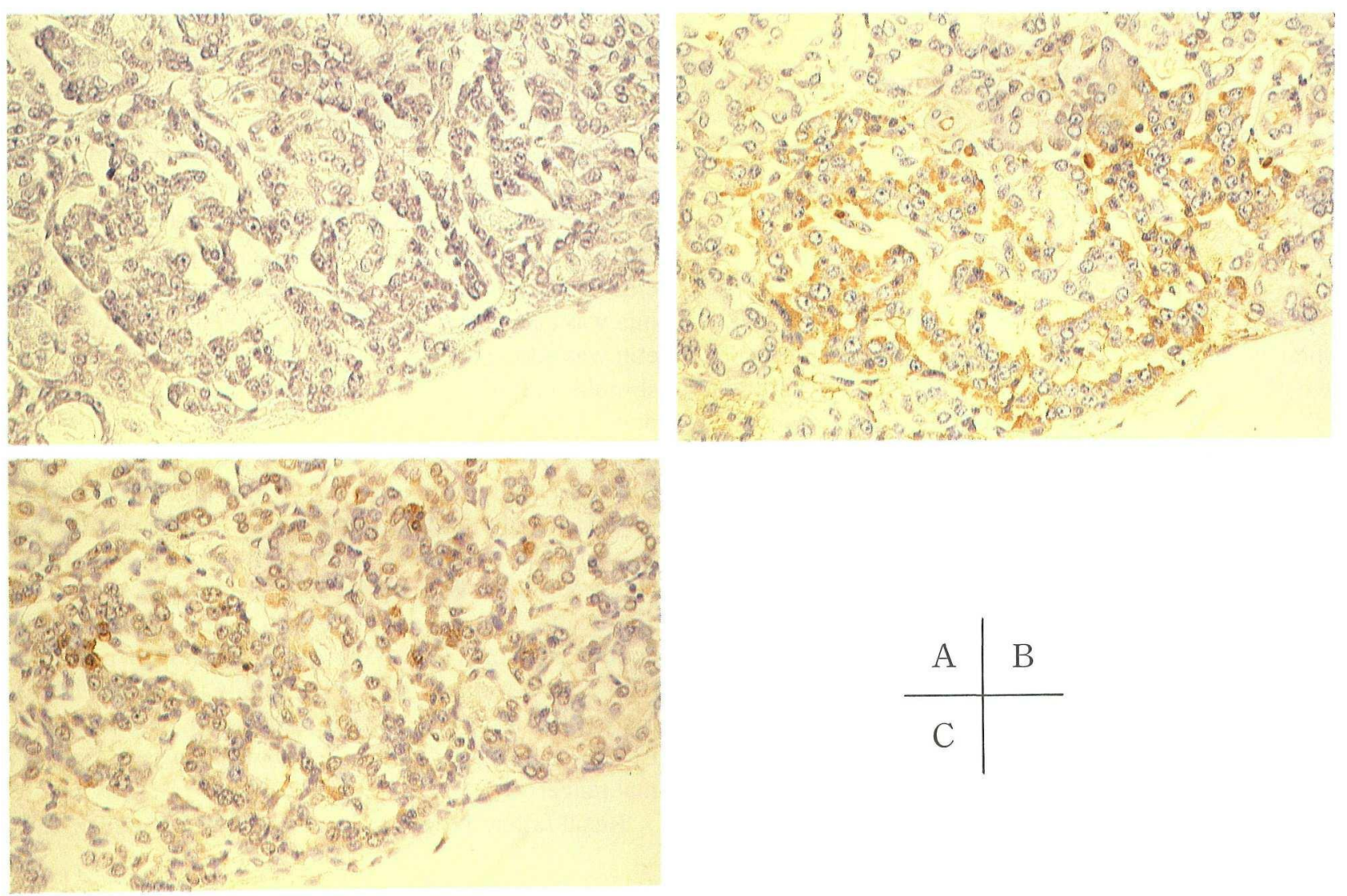

Figure 3. Although glucagon- and somatostatin-containing cells are detected within the islets $(\mathbf{B}, \mathbf{C})$, insulin-containing cells are not detected (A). Immunohistological staining of A) insulin $(\times 100)$, B) glucagon $(\times 100)$, C) somatostatin $(\times 100)$. 
irregular shapes (Figs. 1, 2). Cells positive for insulin were absent (more than 100 islets observed), but glucagon- and somatostatin-positive cells were detected in islets (Fig. 3). Insulitis or periinsulitis was not observed. The deposition of amyloid was observed in a few islets ( 7 of 100 islets observed).

\section{Discussion}

We presented a patient who was positive for GAD Ab 20 years after the diagnosis of diabetes mellitus. Although she was treated with sulphonylurea for 10 years for non-insulin requiring diabetes, her pancreatic $\beta$ cells were almost completely destroyed during the 20 -year history of diabetes.

In the diagnosis of autoimmune-mediated type 1 diabetes, the presence of autoantibodies which react with the islet component is important (1). Several autoantibodies have been reported and GAD Ab, IA-2 Ab and insulin autoantibody are said to be important in detecting type 1A diabetes (3). IA-2 and insulin autoantibody are often detected in the early period of development in type 1 diabetes in the young (4). The negativity of these antibodies did not exclude the presence of autoimmune-mediated type 1 diabetes in this case. Mutation of mitochondrial DNA or hepatocyte nuclear factor- $1 \alpha$ (HNF-1 $\alpha)$ causes severe insulin deficiency and is sometimes misdiagnosed as type 1 diabetes $(5,6)$. Although mutations of these genes were not examined in this case, the lack of family history of diabetes, older onset of diabetes, and positivity for GAD antibody seem not to support the presence of mutations in mitochondrial DNA or HNF-1 $\alpha$.

Type 1 diabetes is a consequence of $T$ cell-mediated destruction of pancreas $\beta$ cells (7). The appearance of autoantibody reacting with islet antigens is considered to be the result of $\beta$ cell destruction. Several cell antigens have been reported to be implicated in the triggering of cell-specific autoimmunity. Among them, the importance of GAD expression on $\beta$ cells in triggering insulitis has been reported in NOD mice (8). Although GAD Ab itself does not participate in $\beta$ cell damage, the positivity for GAD Ab is a good marker for predicting the insulin requirement (9). In typical type 1 diabetes patients who develop ketoacidosis as the first manifestation, the presence of insulitis, which represents autoimmune-mediated $\beta$ cell destruction, has been proven at autopsy or by biopsy $(10,11)$. Damage of $\beta$ cells progresses rapidly and leads to absolute insulin deficiency. In some GAD Ab-positive diabetic patients, the destruction of $\beta$ cells progresses more slowly $(12,13)$, over a decade, as in the present case. The process of $\beta$ cell destruction in such patients arouses interest. In a GAD Ab-positive diabetic patients with residual $\beta$ cell function, the existence of insulitis was reported (14). Insulitis or periinsulitis was not observed and few $\beta$ cells were identified within the disfigured islets in this case. Although it has been reported that histological characteristics in slowly progressing insulin-dependent diabetes patients involve incomplete $\beta$ cell destruction (12), in the present case, the histological findings of the pancreas were those of long-sustained type 1 diabetes(15). When IDDM appears later in life, insulitis is said to be mild (16), and when $\beta$ cells disappear, insulitis ceases. The present patient might have had insulitis for the period of the first 10 years when $\beta$ cell function was maintained. Although deposits of amyloid were observed in a few islets, they were likely due to advanced age rather than to type 2 diabetes (17).

The pancreas of the present case showed marked atrophy. Autopsy findings have revealed a significant reduction in the weight and size of the pancreas in type 1 diabetic patients (18). The paracrine trophic effect of insulin has been shown to be responsible for the reduction in the structure and size of the pancreas (19). Thus, the atrophic pancreas in this case might represent long-term impairment of $\beta$ cell function.

Regarding factors that affect the rate of $\beta$ cell destruction, a positive correlation between high GAD Ab titer and the progression of $\beta$ cell destruction has been reported (18). The titer of GAD Ab was $19.1 \mathrm{U} / \mathrm{ml}$ after 20 years from the onset of diabetes in this patient. As the time course change of GAD Ab titer is unknown in this case, it is difficult to determine the relationship between GAD Ab titer and the rate of $\beta$ cell destruction. This case suggests that the non-insulin-requiring stage in diabetic patients who are positive for GAD Ab may result in complete $\beta$ cell destruction over a decade both clinically and histologically. Intervention that slows the $\beta$ cell damage seems to be important in these patients (12).

Acknowledgements: The authors gratefully appreciate Dr. Jun Iwata, Second Department of Pathology, Kochi Medical School, for his kind evaluation and comments on pancreas specimen.

\section{References}

1) The expert committee on the diagnosis and classification of diabetes mellitus. Report of the expert committee on the diagnosis and classification of diabetes mellitus. Diabetes Care 20: 1183-1197, 1997.

2) Niskanen LK, Tuomi T, Karjalaninen J, Groop LC, Uusitupa MI. GAD antibody in NIDDM. Ten-year follow-up from the diagnosis. Diabetes Care 18: 1557-1565, 1995.

3) Verge CF, Gianani R, Kawasaki E, et al. Prediction of type I diabetes in first-degree relatives using a combination of insulin, GAD, and ICA512bdc/IA-2 autoantibodies. Diabetes 45: 926-933, 1996.

4) Sera Y, Kawasaki E, Abiru N, et al. Autoantibodies to multiple islet autoantigens in patients with abrupt onset of type 1 diabetes and diabetes diagnosed with urinary glucose screening. J Autoimmun 13: 257-265, 1999.

5) Kadowaki T, Kadowaki H, Mori Y, et al. A subtype of diabetes mellitus associated with a mutation of mitochondrial DNA. N Engl J Med 330: 962-968, 1994.

6) Yamada $\mathrm{S}$, Nishigori $\mathrm{H}$, Onda $\mathrm{H}$, et al. Identification of mutations in the hepatocyte nuclear factor (HNF)-1 alpha gene in Japanese subjects with IDDM. Diabetes 46: 1643-1647, 1997.

7) Yoon JW, Jun HS, Santamaria P. Cellular and molecular mechanism for the initiation and progression of beta cell destruction resulting from the collaboration between macrophages and T cells. Autoimmunity 27: 109122, 1998.

8) Yoon JW, Yoon CS, Lim HW, et al. Control of autoimmune diabetes in NOD mice by GAD expression or suppression in beta cells. Science 284: 1183-1187, 1999.

9) Kasuga A, Maruyama T, Nakamoto S, Ozawa Y, Suzuki Y, Saruta T. High titer autoantibodies against glutamic acid decarboxylase plus autoantibodies against insulin and IA-2 predicts insulin requirement in adult diabetic patients. J Autoimmun 12: 131-135, 1999. 


\section{Murao et al}

10) Foulis AK, Liddle CN, Farquharson MA, Richmond JA, Weir RS. The histopathology of the pancreas in type 1 (insulin dependent) diabetes mellitus: a 25 -year review of deaths in patients under 20 years of age in the United kingdom. Diabetologia 29: 267-274, 1986.

11) Ito $N$, Hanafusa $T$, Miyazaki $A$, et al. Mononuclear cell infiltration and its relation to the expression of major histocompatibility complex antigens and adhesion molecules in pancreas biopsy specimens from newly diagnosed insulin-dependent diabetes mellitus patients. J Clin Invest 92: 23132322, 1993.

12) Kobayashi $T$, Tamemoto $K$, Nakanishi $K$, et al. Immunogenetic and clinical characterization of slowly progressive IDDM. Diabets Care 16: 780$788,1993$.

13) Zimmet PZ, Tuomi T, Mackay IR, et al. Latent autoimmune diabetes mellitus in adults (LADA): the role of antibodies to glutamic acid decarboxylase in diagnosis and prediction of insulin dependency. Diabet Med 11: 299-303, 1994.

14) Shimada A, Imazu $Y$, Morinaga $S$, et al. T-cell insulitis found in anti-
GAD65+ diabetes with residual $\beta$-cell function. Diabetes Care 22: 615617, 1999.

15) Gepts W. The pancreas and diabetes, in: Systemic Pathology, 3rd ed, Vol. 12, The Endocrine System, Pewis PL, Ed. Churchill Livingstone, NY, 1996, pp. 221-254.

16) Lernmark $\AA$, Klöppel G, Stenger D, et al. Heterogeneity of islet pathology in two infants with recent onset diabetes mellitus. Virchow Arch 425: 631-640, 1995.

17) Ohsawa H, Kanatsuka A, Mizuno Y, et al. Islet amyloid polypeptide-derived amyloid deposition increases along with the duration of type 2 diabetes mellitus. Diabetes Res Cli Prac 15: 17-21, 1992.

18) Foulis AK, Stewart JA. The pancreas in recent onset type 1 (insulin-dependent) diabetes mellitus: insulin content of islet, insulitis and associated changes in the exocrine acinar tissue. Diabetologia 26: 456-461, 1984.

19) Foulis K, Frier BM. Pancreatic endocrine-exocrine function in diabetes: An old alliance disturbed. Diabet Med 1: 263-266, 1984. 